\title{
KEBIJAKAN FORMULASI PEMBERIAN REMISI YANG BERORIENTASI PADA KEPENTINGAN NARAPIDANA KASUS KORUPSI DALAM SISTEM PERADILAN PIDANA DI INDONESIA DALAM RANGKA PEMENUHAN HAK-HAK NARAPIDANA
}

\author{
Chepi Ali Firman Zakaria \\ Dosen Fakultas Hukum Universitas Islam Bandung \\ e-mail: chepialifirmanzakaria@gmail.com
}

\begin{abstract}
Abstrak-Salah satu tugas dari sistem pemasyarakatan, adalah memberikan pelayanan dan perlindungan terhadap hak-hak narapidana, diantaranya hak untuk mendapatkan remisi, yang diberikan kepada Narapidana dan Anak Pidana. Berkaitan dengan remisi untuk narapidana kasus korupsi, diatur dalam PP Nomor 99 Tahun 2012. Pemberlakuan PP ini menimbulkan pro kontra, karena dianggap memperberat syarat untuk pemberian remisi bagi narapidana yang melakukan tindak pidana berat seperti terorisme, narkotika, dan korupsi. Akibat adanya pro kontra ini, timbul keinginan dari Kemenkumham untuk merevisi PP tersebut, karena dianggap memperberat syarat pemberian remisi.
\end{abstract}

Kata Kunci: Remisi, Hak Narapidana, Keadilan, dan Tujuan Pemidanaan.

Abstract-One of the tasks of the penitentiary system are to provide service and protection of prisoners' rights, including the right to obtain a remission, which is given to the Prisoners and Criminal Children. In connection with the remission to prisoners in corruption cases, stipulated in Government Regulation No. 99 Year 2012. Implementation of this regulation raises the pros and cons because they aggravate the condition of granting remissions for prisoners who commit serious criminal offenses such as terrorism, narcotics, and corruption. Due to the pros and cons of this, the Ministry of Justice and Human Rights. Intend to revise the regulation, because it is considered to aggravate the condition of granting remission.

Keywords: Remission, Prisoners Rights, Justice and Objective of Sentencing.

\section{A. PENDAHULUAN}

Tujuan pemidanaan tidak hanya dikaitkan dengan kepentingan si terdakwa atau korban serta keluarga korban, akan tetapi juga dikaitkan dengan kepentingan masyarakat, sebagaimana dikatakan oleh Barda Nawawi Arief (Barda Nawawi Arief, 1998:26): Tujuan dari kebijakan menetapkan suatu sanksi pidana tidak dapat dilepaskan dari tujuan politik dalam arti keseluruhannya, yaitu perlindungan masyarakat untuk mencapai kesejahteraan. Dari yang dikemukakan oleh Barda Nawawi Arief tersebut, maka perlindungan masyarakat harus menjadi perhatian dalam kebijakan menetapkan sanksi pidana. 
Pembinaan terhadap narapidana yang berorientasi pada masa depan dapat diwujudkan apabila narapidana itu secara sungguh-sungguh menyadari bahwa pidana penjara yang dijatuhkan kepadanya bukanlah dimaksudkan untuk membalas perbuatan yang dilakukan oleh narapidana itu, akan tetapi untuk membina narapidana tersebut ke jalan yang benar agar mereka menjadi manusia yang baik dan bertanggung jawab sesuai dengan harkat dan martabatnya. Pidana penjara tidak semata-mata hanya menimbulkan derita bagi terpidana, akan tetapi juga sebagai salah satu sarana untuk mendidik narapidana agar menyadari kesalahan dan kembali ke jalan yang benar, sebagaimana dikatakan oleh Sahardjo (R. Achmad S. Soemadipradja dan Romli A, 1979:34):

"Di samping menimbulkan rasa derita pada terpidana karena dihilangkannya kemerdekaan bergerak, membimbing narapidana agar bertobat, mendidik supaya ia menjadi seorang anggota masyarakat sosialis Indonesia yang berguna".
Ketentuan Umum Pasal 1 angka 2 Undang-undang Nomor 12 tahun 1995 tentang Pemasyarakatan, menyatakan, bahwa yang dimaksud dengan Sistem Pemasyarakatan adalah:

"Suatu tatanan mengenai arah dan batas serta cara pembinaan Warga Binaan Pemasyarakatan berdasarkan Pancasila yang dilaksanakan secara terpadu antara yang dibina, dan masyarakat untuk meningkatkan kualitas Warga Binaan Pemasyarakatan agar menyadari kesalahan, memperbaiki diri, dan tidak mengulangi tindak pidana sehingga dapat diterima kembali oleh lingkungan masyarakat, dapat aktif berperan dalam pembangunan, dan dapat hidup secara wajar sebagai warga negara yang baik dan bertanggung jawab".

Menurut Andi Hamzah tujuan pemasyarakatan sebenarnya ada dua (Andi Hamzah, 1985:90), yaitu:

1. Memasukkan bekas narapidana ke dalam masyarakat sebagai warga yang baik (jika berdasar perikemanusiaan).

2. Melindungi masyarakat dari kambuhnya kejahatan bekas narapidana dalam masyarakat karena tidak mendapatkan pekerjaan.

Konsep pemidanaan yang dahulu dipakai kini sudah tidak lagi sebagai suatu tindakan penghukuman 
atau pembalasan, tetapi konsep yang digunakan sekarang ini adalah konsep pembinaan atau rehabilitasi. Dalam Undang-undang Nomor 12 Tahun 1995 tentang Pemasyarakatan di dalamnya telah menegaskan sistem pemasyarakatan diselenggarakan dalam rangka membentuk warga binaan pemasyarakatan agar menjadi manusia yang seutuhnya, menyadari kesalahan, memperbaiki diri dan tidak mengulangi tindak pidana, sehingga dapat diterima kembali oleh masyarakat, dapat aktif berperan dalam pembangunan dan dapat hidup secara wajar sebagai warga yang baik dan bertanggung jawab dalam lingkungan masyarakat. Dalam hal ini pemasyarakatan bertugas untuk memberikan perlindungan terhadap hak-hak terpidana dan terpidana tersebut harus diperlakukan secara manusiawi sesuai dengan asas yang secara eksplisit ditegaskan dalam Pasal 5 Undang-undang Nomor 12 Tahun 1995, bahwa Sistem Pembinaan Pemasyarakatan dilaksanakan harus berdasarkan asas sebagai berikut:

1. Pengayoman;

2. Persamaan perlakuan dan pelayanan;
3. Pendidikan;

4. Pembimbingan;

5. Penghormatan harkat dan martabat manusia;

6. Kehilangan kemerdekaan merupakan satu-satunya penderitaan; dan

7. Terjaminnya hak untuk tetap berhubungan dengan keluarga dan orang-orang tertentu.

Selain itu pemasyarakatan pun bertugas untuk memberikan pelayanan dan perlindungan terhadap hak-hak narapidana, diantaranya hak untuk mendapatkan remisi, yaitu pengurangan masa pidana yang diberikan kepada narapidana dan anak pidana yang memenuhi syarat-syarat yang ditentukan dalam peraturan perundang-undangan. Aturan dasar yang mengatur pemberian remisi bagi narapidana yang berkelakuan baik terdapat dalam ketentuan Pasal 14 ayat (1) huruf I Undang-undang Nomor 12 Tahun 1995. Remisi merupakan suatu hak bagi setiap narapidana, tetapi hak tersebut tidak diperoleh secara otomatis, tetapi dengan syarat atau kriteria tertentu.

Pengertian remisi terdapat dalam Pasal 1 ayat (6) Peraturan Pemerintah Nomor 32 Tahun 1999, yaitu Remisi adalah pengurangan masa pidana yang diberikan kepada 
narapidana dan anak pidana yang telah memenuhi syarat-syarat yang ditentukan dalam peraturan perundang-undangan. Menurut Kamus Hukum, remisi adalah pengampunan hukuman yang diberikan kepada seseorang yang dijatuhi pidana (Sudarsono, 2007:402).

Dalam sistem pemasyarakatan Indonesia terdapat beberapa jenis remisi

\section{(http://www.depkumham.go.id),}

yaitu: Remisi Umum, Remisi Khusus, Remisi Tambahan, dan Remisi

\section{Dasawarsa.}

Syarat Pemberian remisi bagi seorang narapidana didasarkan pada Pasal 34 ayat (2) dan ayat (3)

Peraturan Pemerintah Nomor 32 Tahun 1999 tentang Syarat dan Tata Cara Pelaksanaan Hak Warga Binaan Pemasyarakatan, yaitu:

1. Berkelakuan baik, berkelakuan baik mempunyai syarat yang harus dipenuhi yaitu:

a. Tidak sedang menjalani hukuman disiplin dalam kurun waktu 6 (enam) bulan terakhir, terhitung sebelum tanggal pemberian remisi;

b. Telah mengikuti program pembinaan yang diselenggarakan oleh LAPAS dengan predikat baik.
2. Telah menjalani masa pidana lebih dari 6 (enam) bulan.

Selain syarat yang terdapat dalam Pasal 34 tersebut, ada persyaratan lain yang harus dipenuhi bagi narapidana yang melakukan tindak pidana terorisme, narkotika, korupsi, kejahatan terhadap keamanan negara, kejahatan hak asasi manusia yang berat, serta kejahatan transnasional terorganisasi lainnya yang terdapat dalam Pasal 34A ayat (1) Peraturan Pemerintah Nomor 99 Tahun 2012, yaitu:

1. Bersedia bekerjasama dengan penegak hukum untuk membantu membongkar perkara tindak pidana yang dilakukannya;

2. Telah membayar lunas denda dan uang pengganti sesuai dengan putusan pengadilan untuk narapidana yang dipidana karena melakukan tindak pidana korupsi;

3. Telah mengikuti program deradikalisasi yang diselenggarakan oleh LAPAS dan/atau Badan Nasional Penanggulangan Terorisme, serta menyatakan ikrar:

a. Kesetiaan kepada Negara Kesatuan Republik Indonesia secara tertulis bagi Narapidana Warga Negara Indonesia, atau

b. Tidak akan mengulangi perbuatan tindak pidana terorisme secara tertulis bagi Narapidana Warga Negara Asing, yang dipidana karena 
melakukan tindak pidana terorisme.

Pemberlakuan Peraturan Pemerintah ini menimbulkan pro kontra, karena dianggap memperberat syarat untuk pemberian remisi bagi narapidana yang melakukan tindak pidana terorisme, narkotika, korupsi, kejahatan terhadap keamanan negara, kejahatan hak asasi manusia yang berat, serta kejahatan transnasional terorganisasi lainnya. Pro kontra terhadap revisi PP Nomor 99 Tahun 2012 ini selain berkaitan dengan dasar hukum pemberian remisi, juga berkaitan dengan substansi dari PP tersebut.

\section{B. HASIL DAN PEMBAHASAN}

Konsep pemidanaan yang dahulu dipakai kini sudah tidak lagi sebagai suatu tindakan penghukuman atau pembalasan, tetapi konsep yang digunakan sekarang ini adalah konsep pembinaan atau rehabilitasi. Dalam Undang-undang Nomor 12 Tahun 1995 tentang Pemasyarakatan di dalamnya telah ditegaskan sistem pemasyarakatan diselenggarakan dalam rangka membentuk warga binaan pemasyarakatan agar menjadi manusia yang seutuhnya, menyadari kesalahan, memperbaiki diri dan tidak mengulangi tindak pidana, sehingga dapat diterima kembali oleh masyarakat, dapat aktif berperan dalam pembangunan dan dapat hidup secara wajar sebagai warga yang baik dan bertanggung jawab dalam lingkungan masyarakat.

Oleh karena itu pada saat di dalam lembaga pemasyarakatan mereka diberikan pendidikan dan pembekalan keterampilan, sehingga mereka dapat berguna bagi kehidupan dan memiliki keahlian ketika mereka keluar dari lembaga pemasyarakatan tersebut. Dalam hal ini pemasyarakatan bertugas untuk memberikan perlindungan terhadap hak-hak terpidana dan terpidana tersebut harus diperlakukan secara manusiawi sesuai dengan asas yang secara eksplisit ditegaskan dalam Pasal 5 Undang-undang Nomor 12 Tahun 1995.

Berkaitan dengan hak untuk mendapatkan remisi, di Indonesia pemberian remisi tidak dapat dipisahkan dengan sistem pemasyarakatan yang telah ada sebelumnya. Sistem Pemasyarakatan 
ini memiliki tujuan yaitu mengupayakan warga binaan untuk tidak mengulangi lagi perbuatannya melanggar hukum yang pernah dilakukan sebagai warga masyarakat serta dapat berperan aktif sebagaimana anggota masyarakat lainnya. Dengan adanya remisi ini maka, didalamanya terdapat kedudukan yang seimbang dalam pembinaan yang dilakukan di Lembaga Pemasyarakatan. Oleh karena itu, remisi ini merupakan hak yang diberikan kepada narapidana khususnya pelaku tindak pidana korupsi. Dalam sistem pemasyarakatan, pemidanaan tidak masuk ke dalam aspek penjeraan saja, melainkan juga aspek pembinaan dan rehabilitasi. Remisi ini merupakan salah satu hak dari narapidana yang merupakan keberhasilan yang telah dicapai karena remisi ini pada dasarnya diberikan kepada narapidana yang berkelakuan baik selama menjalani pidana di Lembaga Pemasyarakatan.

Remisi merupakan suatu bagian dari pembinaan yang tidak dapat dipisahkan karena remisi merupakan hak yang diberikan kepada narapidana. Tujuan dari pemberian remisi ini adalah agar narapidana mempunyai keinginan untuk tidak mengulangi perbuatan yang melanggar hukum dan dapat berkelakuan baik hingga berperan aktif dalam kehidupan bermasyarakat saat bebas nanti.

Berdasarkan Peraturan Pemerintah Republik Indonesia Nomor 32 Tahun 1999 Pasal 1 angka 6, pengertian remisi adalah pengurangan masa menjalani pidana yang diberikan kepada narapidana dan anak pidana yang memenuhi syarat-syarat yang ditentukan dalam Peraturan perundang-undangan. Pasal 1 Keputusan Presiden Republik Indonesia Nomor 174 Tahun 1999 tidak memberikan pengertian remisi, hanya mengatakan bahwa:

"Setiap narapidana dan anak pidana yang menjalani pidana penjara sementara dan pidana kurungan dapat diberikan remisi apabila yang bersangkutan berkelakuan baik selama menjalani pidana".

Menurut Andi Hamzah, remisi merupakan pengurangan hukuman untuk seluruhnya atau sebagian atau dari seumur hidup menjadi hukuman 
terbatasyang diberikan setiap tanggal 17 Agustus.

Sebagai salah satu hak narapidana, remisi mempunyai kedudukan yang strategis untuk memperbaiki perilaku narapidana. Dengan adanya remisi ini maka, narapidana diberikan kesempatan untuk memperbaiki dirinya hal ini berguna agar narapidana dapat diterima kembali di masyarakat. Di dalam Lembaga Pemasyarakatan narapidana dimotivasi untuk berbuat baik agar mendapatkan remisi, tetapi untuk mendapatkan remisi tersebut tidak hanya harus memenuhi syarat berkelakuan baik saja, khususnya narapidana pelaku tindak pidana korupsi dan teorisme, mereka harus memenuhi syarat tambahan sebagaimana terdapat dalam Pasal 34A Peraturan Pemerintah Nomor 99 Tahun 2012.

Oleh sebagian kalangan, bahkan Kemenkumham menilai, bahwa PP Nomor 99 Tahun 2012 dianggap tidak adil dan diskriminasi dalam memberikan remisi terhadap narapidana kasus tertentu. Syaratsyarat yang diatur dalam PP tersebut dianggap memberatkan.
Perlindungan hukum narapidana dapat diartikan sebagai upaya perlindungan hukum terhadap berbagai kebebasan dan hak asasi narapidana (fundamental rights and freedoms of prisoners) serta berbagai kepentingan yang berhubungan dengan kesejahteraan narapidana (Barda Nawawi Arief, 1998:155). Perlindungan hukum atas hak-hak narapidana di Indonesia sebenarnya telah diatur dalam Undang-undang Nomor 39 Tahun 1999 tentang HakAsasi Manusia, dan Undang-undang Nomor 12 Tahun 1995 tentang Pemasyarakatan. Inti perlindungan narapidana adalah terwujudnya pembinaan narapidana sesuai dengan sistem pemasyarakatan yang diberlakukan dalam Undang-undang Pemasyarakatan.

Perlindungan terhadap hak-hak narapidana, salah satunya adalah hak untuk mendapatkan remisi, merupakan perwujudan dari adanya jaminan terhadap hak asasi manusia, yang merupakan salah satu ciri dari Negara Hukum termasuk Negara Hukum Pancasila.

Menurut Friedrich Julius Stahl, cici-ciri Negara hukum itu (S. F. 
Marbun dan Moh. Mahfud MD, 1989:151) adalah sebagai berikut:

1. Adanya perlindungan hak-hak asasi manusia;

2. Pemisahan atau pembagian kekuasaan untuk menjamin hakhak asasi manusia;

3. Pemerintahan berdasarkan peraturan-peraturan; dan

4. Adanya peradilan administrasi Negara dalam perselisihan.

Sri Soemantri mengemukakan unsur-unsur terpenting Negara hukum

(Sri Soemantri M, 1992:29-30), yaitu:

1. Bahwa pemerintah dalam melaksanakan tugas dan kewajibannya harus berdasar atas hukum atau perundang-undangan;

2. Adanya jaminan terhadap hak asasi manusia (warga Negara);

3. Adanya pembagian kekuasaan;

4. Adanya pengawasan dari badanbadan peradilan (rechterlijke controle).

Padmo menyatakan dalam

Negara hukum terdapat suatu pola

(Padmo Wahjono, 1979:6) sebagai berikut:

1. Menghormati dan melindungi hakhak manusia;

2. Mekanisme kelembagaan negara yang demokratis;

3. Tertib hukum;

4. Kekuasaan kehakiman yang bebas.

Prinsip persamaan tersebut secara teoritis atau praktis tidak hanya mencakup bidang politik, hukum dan sosial, tetapi juga bidang ekonomi dan kebudayaan. Penegakan prinsip persamaan ini menjadi prasyarat yang mendukung eksistensi Negara Hukum Pancasila dalam upaya mengaktualisasikan atau mengimplementasikan komitmennya untuk menyejahterakan kehidupan lapisan masyarakat sebagai misi peneyelenggaraan pemerintahan.

Dengan adanya pengetatan pemberian remisi yang tercantum dalam Peraturan Pemerintah Nomor 99 Tahun 2012 tentang Perubahan Kedua Atas Peraturan Pemerintah Nomor 32 Tahun 1999 Tentang Syarat dan Tata Cara Pelaksanaan Hak Warga Binaan Pemasyarakatan, maka untuk mendapatkan remisi pelaku tindak pidana sekarang ini cukup sulit dibandingkan peraturan yang sebelumnya, karena terkait dengan syarat yang ada. Hal ini berbeda sebelum adanya pengetatan dalam pemberian remisi tersebut.

Kelebihan dari Peraturan Pemerintah Nomor 99 Tahun 2012 ini adalah dapat membantu pemerintah dalam membongkar kasus tindak pidana tersebut, karena adanya 
bantuan dari pelaku tindak pidana dan syaratnya lebih sulit dibandingkan aturan sebelumnya. Dalam PP ini ada kriteria khusus yang bersifat pengeksklusifan perlakuan yang diberikan kepada narapidana, dan hal ini berbeda dengan Undang-undang Nomor 12 Tahun 1995, yang tidak membedakan perlakuan terhadap semua narapidana.

Berkaitan dengan pro kontra pemberian remisi kepada narapidana korupsi, dan rencana Kemenkumham untuk merevisi PP Nomor 99 Tahun 2012, karena dianggap memberatkan pemberian remisi kepada narapidana pelaku tindak pidana tertentu yang dianggap berat, maka perlu diperhatikan Putusan Mahkamah Agung Nomor Nomor 51 P/HUM/2013 yang telah memberikan legitimasi yang sangat kuat bagi pelaksanaan PP 99 Tahun 2012, sehingga tidak ada alasan diskriminatif dan melanggar hak narapidana korupsi yang dinyatakan sebelumnya oleh pemerintah.

$$
\text { Menurut pertimbangannya }
$$

Mahkamah Agung menyatakan bahwa:
“...Bahwa tidak ternyata ada pertentangan antara Peraturan Pemerintah Nomor 99 Tahun 2012 dengan Undang-Undang Nomor 12 Tahun 1995 karena tujuan utama dari Peraturan Pemerintah Nomor 99 Tahun 2012 adalah pembinaan narapidana. Pembinaan yang berbeda terhadap narapidana, merupakan konsekuensi logis adanya perbedaan karakter jenis kejahatan yang dilakukan narapidana, perbedaan sifat berbahayanya kejahatan yang dilakukan dan akibat yang ditimbulkan oleh tindak pidana yang dilakukan oleh masingmasing narapidana;

"...bahwa keberadaan Peraturan Pemerintah Nomor 99 Tahun 2012 memperketat syarat pemberian Remisi agar pelaksanaannya mencerminkan nilai keadilan. Sehingga menunjukkan pembedaan antara pelaku tindak pidana yang biasa atau ringan dengan tindak pidana yang menelan biaya yang tinggi secara sosial, ekonomi, dan politik yang harus ditanggung oleh Negara dan/atau rakyat Indonesia. Dengan demikian, perbedaan perlakuan merupakan konsekuensi etis untuk memperlakukan secara adil sesuai dengan dampak kerusakan moral, sosial, ekonomi, keamanan, generasi muda, dan masa depan bangsa, dari kejahatan yang dilakukan masing-masing narapidana.

“...korupsi di Indonesia telah merampas hak-hak dasar social dan ekonomi dari rakyat 
Indonesia dan berlangsung secara sistemik dan meluas sehingga menjadi kejahatan luar biasa (extra ordinary crimes); ...Dengan adanya Peraturan Pemerintah Nomor 99 Tahun 2012 justru menunjukkan adanya konsistensi roh atau spirit penanggulangan kejahatan berat atau yang bersifat Extra Ordinary Crimes, agar kejahatan tersebut tidak sampai meruntuhkan tatanan social dalam masyarakat bangsa Indonesia.

"...Menimbang, bahwa rejim Undang-Undang

Pemasyarakatan adalah Rejim pelaksanaan pemidanaan dan pemasyarakatan/pembinaan. In casu, Peraturan Pemerintah Nomor 99 Tahun 2012 ternyata tidak menghilangkan hak-hak narapidana dalam rangka menjalani pidana yang dijatuhkan oleh Rejim Pengadilan, melainkan melaksanakan proses pelaksanaan pemidanaan tersebut secara efektif dan pembinaan yang tepat agar tujuan pemidanaan tersebut dapat tercapai maksimal. Oleh sebab itu, antara UndangUndang dan Peraturan Pemerintah objek Hak Uji Materiil tidak terdapat "irrelevansi ideolistik Hukum" didalamnya, dan tidak pula terdapat pelanggaran terhadap asas "Kewerdaan/ penjenjangan" peraturan perundang-undangan;

“...Menimbang, bahwa adanya pengaturan pengetatan pemberian hak tersebut terhadap kejahatan tertentu yang memang menjadi prioritas untuk diberantas adalah dapat diterima. Khusus terhadap pelaku tindak pidana korupsi, sebenarnya merupakan pihak yang berpotensi merusak kemungkinan warganegara untuk mendapatkan segala macam jaminan hak ekonomi, social dan budaya yang termuat dalam ketentuan Pasal 22 DUHAM. Hal tersebut sudah menjadi masalah serius yang telah mengancam stabilitas dan keamanan nasional dan internasional, melemahkan institusi dan nilai-nilai demokrasi dan keadilan serta membahayakan pembangunan dan penegakan hukum;

“...Menimbang, bahwa Peraturan Pemerintah Nomor 99 Tahun 2012 tidak bertentangan dengan Pasal 5 dan Pasal 6 Undang-Undang Nomor 12 Tahun 2011; Menimbang, bahwa dalam pembentukan Peraturan Pemerintah Nomor 99 Tahun 2012 telah mendasarkan pada Pasal 5 dan 6 Undang-Undang Nomor 12 Tahun 2011 karena keberadaan Peraturan Pemerintah Nomor 99 Tahun 2012 merupakan perintah Pasal 14 ayat (2) Undang-Undang Nomor 12 Tahun 1995 dan dalam pembentukannya telah memenuhi asas-asas pembentukan peraturan perundang-undangan yang baik, yaitu: kejelasan tujuan, kelembagaan atau pejabat pembentuk yang tepat, 
kesesuaian antara jenis, itu sendiri, termasuk juga bagaimana hierarki dan materi muatan dapat dilaksanakan, kedayagunaan dan kehasilgunaan, kejelasan rumusan dan keterbukaan".

Dengan adanya Putusan Mahkamah Agung ini, maka pemerintah diharapkan konsisten dengan aturan yang dibuatnya sendiri, dan juga berhati-hati dalam mengeluarkan kebijakan agar tidak bertentangan dengan peraturan perundang-undangan yang ada.

Keadilan adalah sesuatu yang dicari oleh manusia, sebagai khalifah atau penguasa di bumi. Sebagai penguasa, maka tugasnyalah menegakkan keadilan. Allah menegaskan bahwa hanya orang yang beiman yang mampu menegakkan keadilan, menjadi saksi yang adil dan tidak mengikuti hawa nafsu. Orang yang menegakkan hukum dengan adil, dikatagorikan lebih dekat kepada taqwa.

Apabila dihubungkan dengan konsep keadilan menurut John Rawls, maka keadilan itu tidak saja meliputi konsep moral tentang individunya, tetapi juga mempersoalkan mekanisme dari pencapaian keadilan 
kerugian sepihak. Kewajiban- mandat sosial oleh publik. Karena itu kewajiban tersebut secara ringkas penguasa harus bertanggung jawab dapat disimpulkan dalam dua hal, untuk menegakkan keadilan seadilyaitu: Menunaikan amanah, dan adilnya, dan menetapkan hukum menegakkan hukum dengan adil kepada seluruh umat. Mengatur kepentingan negara sesuai dengan tuntutannya, sehingga membawa kebaikan bagi individu maupun jama'ah, ke dalam maupun ke luar.

Mewujudkan keadilan yang objektif adalah sikap yang sangat sulit untuk dicapai oleh manusia, disebabkan oleh kodrat manusia dengan kecenderungan mengikuti hawa nafsu. Karena itulah banyak ulama yang menolak dirinya dipromosikan menjadi hakim, bukan karena mereka enggan untuk menghakimi suatu masalah, tetapi karena mereka khawatir kalau-kalau ia tidak mampu mewujudkan keadilan yang objektif disebabkan oleh emosi ataupun hawa nafsu yang menyelimuti dirinya (Muhammad Mutawalli Sya'rawi, 2005:21-26).

Semua jenis keadilan tersebut, oleh Al-Qur'an ditugaskan untuk ditegakkan oleh penguasa karena mereka mempunyai kekuatan/power sekaligus penguasa itu telah diberi dengan adil meskipun pada manusia terdapat keterbatasan dan inilah sebuah relativitas manusia.

Berdasarkan uraian di atas, maka sudah seharusnya pemberian remisi kepada narapidana korupsi dilakukan sesuai dengan aturan, secara profesional dan proporsional. Narapidana yang ingin mendapatkan remisi dituntut untuk memenuhi persyaratan yang sudah ditetapkan dalam peraturan perundangundangan, dan melalui prosedur yang ditetapkan. Aturan mengenai remisi dibuat untuk menciptakan kepastian hukum, kemanfaatan, dan keadilan dalam pemberian remisi tersebut.

\section{SIMPULAN}

1. Kebijakan formulasi pemberian remisi kepada narapidana kasus korupsi diatur dalam beberapa peraturan perundang-undangan. Kebijakan ini dimaksudkan untuk perlindungan dan 
pemenuhan hak remisi narapidana tersebut.

Narapidana, seperti halnya manusia pada umumnya mempunyai hak-hak yang juga harus dilindungi dan dipenuhi oleh undang-undang. Hak-hak yang harus dilindungi dan dipenuhi tersebut, baik hak-hak yang sifatnya non-derogable rigths, yakni hak-hak yang tidak dapat diingkari atau diganggu gugat oleh siapapun dan dalam keadaan apapun, maupun hak yang bisa dikesampingkan atau disimpangi, seperti hak mendapatkan remisi. Sesuai dengan Putusan Mahkamah Agung Nomor $\quad 51$ P/HUM/2013, Peraturan Pemerintah Nomor 99 Tahun 2012 tentang Perubahan Kedua atas Peraturan Pemerintah Nomor 32 Tahun1999 tentang Syarat dan Tata Cara Pelaksanaan Hak Warga Binaan Pemasyarakatan, tidak menghilangkan hak-hak narapidana dalam rangka menjalani pidana yang dijatuhkan oleh Pengadilan, melainkan melaksanakan proses pelaksanaan pemidanaan tersebut secara efektif dan pembinaan yang tepat agar tujuan pemidanaan tersebut dapat tercapai maksimal.

2. Dihubungkan dengan nilai keadilan, maka pemberian remisi kepada narapidana kasus korupsi adalah adil, sepanjang pemberian remisi tersebut mengacu kepada syarat-syarat yang diatur dalam peraturan perundang-undangan yang berlaku. Penambahan syarat pemberian remisi sebagaimana diatur dalam Peraturan Pemerintah Nomor 99 Tahun 2012 tentang Perubahan Kedua atas Peraturan Pemerintah Nomor 32 Tahun 1999 tentang Syarat dan Tata Cara Pelaksanaan Hak Warga Binaan Pemasyarakatan, dikatakan adil, karena penambahan syarat tersebut merupakan konsekuensi logis dari sifat tindak pidana korupsi, yang digolongkan sebagai extra ordinary crimes. Penambahan Syarat tersebut menunjukkan 
perbedaan antara pelaku tindak pidana yang biasa atau ringan dengan tindak pidana yang menelan biaya yang tinggi secara sosial, ekonomi, dan politik yang harus ditanggung oleh Negara dan/atau rakyat Indonesia. Dengan demikian, perbedaan perlakuan merupakan konsekuensi etis untuk memperlakukan secara adil sesuai dengan dampak kerusakan moral, sosial, ekonomi, keamanan, generasi muda, dan masa depan bangsa, dari kejahatan yang dilakukan masing-masing narapidana.

3. Dihubungkan dengan tujuan pemidanaan, penambahan syarat pemberian remisi kepada narapidana kasus korupsi merupakan perwujudan dari teori gabungan/integratif, yaitu selain bertujuan membalas kesalahan terpidana juga dimaksudkan untuk melindungi masyarakat, dengan mewujudkan ketertiban. Penambahan syarat pemberian remisi menunjukkan adanya konsistensi roh atau spirit penanggulangan kejahatan berat, agar kejahatan tersebut tidak sampai meruntuhkan tatanan sosial dalam masyarakat bangsa Indonesia. Pelaku korupsi merupakan pihak yang berpotensi merusak kemungkinan warga negara untuk mendapatkan segala macam jaminan hak ekonomi, sosial dan budaya. Korupsi sudah menjadi masalah serius yang mengancam stabilitas dan keamanan nasional dan internasional, melemahkan institusi dan nilai-nilai demokrasi dan keadilan serta membahayakan pembangunan dan penegakan hukum. Penambahan syarat ini tidak menghilangkan hak narapidana kasus korupsi untuk menerina remisi. Pemberian remisi ini merupakan hak narapidana yang juga diberikan dibeberapa negara lain dan diatur dalam instrumen internasional, misalnya diatur dalam Standard Mininum Rules for the Treatment of Prisoners (Standar Aturan Mininum 
PerlakuanTerhadap Narapidana) tahun 1977. pemberian remisi yang diberikan oleh Kemenkumham.

\section{SARAN}

1. Seharusnya

Peraturan

Pemerintah Nomor 99 Tahun

2012 diberlakukan bagi semua narapidana kasus korupsi. Hal ini untuk menghindari diskriminasi dalam pemberian remisi, karena masih berlakunya Peraturan Pemerintah Nomor 28 Tahun 2006.

2. Berkaitan dengan pemberian remisi kepada narapidana kasus korupsi, seharusnya pemerintah cq Kemenkumham konsisten dan kosekuen melaksanakan Peraturan Pemerintah Nomor 99 Tahun 2012, yang telah mendapat legitimasi dengan Putusan Mahkamah Agung Nomor 51 P/HUM/2013.

3. Di masa yang akan datang, ketentuan mengenai remisi seharusnya diatur dalam undang-undang. Hal ini dimaksudkan untuk meningkatkan pengawasan

\section{DAFTAR PUSTAKA}

Al'Quran dan Terjemahnya. Mujamma Al Malik Fahd Lithiba At Al Mushhaf, Kerajaan Arab Saudi, 1990.

Andi Hamzah, Sistem Pidana dan Pemidanaan Indonesia dari Retribusi ke Reformasi, Pradnya Paramita, Jakarta, 1985. Kamus Hukum, Ghalia Indonesia, Jakarta. 2000.

Barda Nawawi Arief, Beberapa Aspek Kebijakan Penegakan dan Pengembangan Hukum Pidana, Citra Aditya bakti, Bandung, 1998.

Muhammad Mutawalli Sya'rawi, Adalatullah: Keadilan dan Hidayah Allah, terjemahan. Ahsan Askan, Cendekia, Jakarta, 2005.

Muladi dan Barda Nawawi Arief, Teori-teori dan Kebijakan Pidana, Edisi Revisi, Alumni, Bandung, 1998.

Nainggolan, Jogi, Energi Hukum Sebagai Faktor Pendorong Efektivitas Hukum, PT. Refika Aditama, Bandung, 2015.

Padmo Wahjono, Pembangunan Hukum Indonesia, In Hill Co. Jakarta, 1989. 
R. Achmad S. Soemadipradja dan Romli A, Sistem Pemasyarakatan di Indonesia, Bina Cipta, Bandung, 1979.

Ronny Hanitijo Soemitro, Metodologi Penelitian Hukum dan Jurimetri, Cetakan ketiga, Ghalia Indonesia, Jakarta, 1988.

S.F Marbun dan Moh. Mahfud MD, Pokok-pokok Hukum Administrasi Negara, Liberty, Yogyakarta, 1987.

Sri Soemantri M, Bunga Rampai Hukum Tata Negara Indonesia, Penerbit Alumni, Bandung, 1992.

Soerjono Soekanto dan Sri Mamudji, Penelitian Hukum Normatif Suatu Tinjauan Singkat, Rajawali Pers, Jakarta, 1985.

Soerjono Soekanto, Metode Penelitian Hukum, UI Press, Jakarta, 2002.

Sudarsono, Kamus Hukum, Rineka Cipta, Jakarta, 2007.

Padmo Wahjono, Indonesia Negara yang Berdasarkan Atas Hukum, Pidato pengukuhan Guru Besar FHUI, Jakarta, 17 November 1979.

Undang-undang Nomor 12 Tahun 1995 tentang Pemasyarakatan.
Undang-undang Nomor 39 Tahun 1999 tentang Hak Asasi Manusia.

Peraturan Pemerintah Republik Indonesia Nomor 32 Tahun 1999 Tentang Syarat dan Tata Cara Pelaksanaan Hak Warga Binaan Pemasyarakatan.

Peraturan Pemerintah Republik Indonesia Nomor 28 Tahun 2006 Tentang Perubahan Atas Peraturan Pemerintah Nomor 32 Tahun 1999 Tentang Syarat Dan Tata Cara Pelaksanaan Hak Warga Binaan Pemasyarakatan.

Peraturan Pemerintah Republik Indonesia Nomor 99 Tahun 2012 Tentang Perubahan Kedua Atas Peraturan Pemerintah Nomor 32 Tahun 1999 Tentang Syarat Dan Tata Cara Pelaksanaan Hak Warga Binaan Pemasyarakatan.

Keputusan Presiden Republik Indonesia Nomor 174 Tahun 1999 Tentang Remisi.

Putusan Mahkamah Konstitiusi Nomor 49/PUU-X/2012 Perihal Pengujian Undang-Undang Nomor 30 Tahun 2004 tentang Jabatan Notaris.

Putusan Mahkamah Agung Nomor 51 P/HUM/2013.

http://www.depkumham.go.id. 